\title{
Rockfall hazard mapping along a mountainous road in Switzerland using a GIS-based parameter rating approach
}

\author{
F. Baillifard ${ }^{1,2}$, M. Jaboyedoff ${ }^{1,3}$, and M. Sartori ${ }^{1,4}$ \\ ${ }^{1}$ CREALP - Research Center on Alpine Environment, Industrie 45, 1951 Sion, Switzerland \\ ${ }^{2}$ Institute of Geology and Paleontology, University of Lausanne, BFSH2, 1015 Lausanne, Switzerland \\ ${ }^{3}$ Quanterra, Chemin Tour-Grise 28, 1007 Lausanne, Switzerland \\ ${ }^{4}$ Department of Geology and Paleontology, University of Geneva, Maraîchers 13, 1211 Genève 4, Switzerland
}

Received: 8 July 2002 - Revised: 24 February 2003 - Accepted: 25 February 2003

\begin{abstract}
A posteriori studies of rock slope instabilities generally show that rockfalls do not occur at random locations: the failure zone can be classified as sensitive from geomorphological evidence. Zones susceptible to failure can therefore be detected. Effects resulting from degrading and triggering factors, such as groundwater circulation and freeze and thaw cycles, must then be assessed in order to evaluate the probability of failure.

A simple method to detect rock slope instabilities was tested in a study involving a $2000 \mathrm{~m}^{3}$ rockfall that obstructed a mountainous road near Sion (Switzerland) on 9 January 2001. In order to locate areas from which a rockfall might originate, areas were assessed with respect to the presence or absence of five criteria: (1) a fault, (2) a scree slope within a short distance, (3) a rocky cliff, (4) a steep slope, and (5) a road. These criteria were integrated into a Geographic Information System (GIS) using existing topographic, geomorphological, and geological vector and raster digital data. The proposed model yields a rating from 0 to 5, and gives a relative hazard map. Areas yielding a high relative hazard have to meet two additional criteria if they are to be considered as locations from which a rockfall might originate: (1) the local structural pattern has to be unfavourable, and (2) the morphology has to be susceptible to the effects of degrading and triggering factors. The rockfall of 9 January 2001, has a score of 5. Applied to the entire length of the road $(4 \mathrm{~km})$, the present method reveals two additional areas with a high relative hazard, and allows the detection of the main instabilities of the site.
\end{abstract}

\section{Introduction}

Based on the 2001 Eterpas rockfall that occurred along a road near Sion (central canton of Valais, Switzerland), an automatic method was devised to detect potential rock slope

Correspondence to: F. Baillifard

(francois.baillifard@crealp.ch) instabilities in similar morphological contexts. Such an approach is useful because rock instabilities are a common threat to mountainous roads (Brawner, 1994; Carere et al., 2001; Fard, 2001). The economic impact of rockfalls is potentially important because they often lead to traffic disruptions or delays, and require remedial measures (Turner and Schuster, 1996). The identification of areas from which a rockfall might originate, and the assessment of the hazard of unstable areas, allows for the implementation of stabilization or protective measures before the occurrence of a catastrophic event, thereby reducing costs significantly (Carere et al., 2001; Crosta et al., 2001). For example, precursory rockfalls led to the closure of the road to traffic one hour before the 2001 Eterpas rockfall. The traffic was then disrupted for a period of two weeks in order to rebuild the road and re-scale the cliff.

Various methods can be used to assess landslide hazard, though very few are dedicated to rockfalls on a regional scale (Wagner et al., 1990; Meissina et al., 2001). Studies of rockfalls are often based on field surveys, and hazard is estimated either by an empirical assessment of the susceptibility to failure, or by the calculation of a safety factor derived from models of rock mechanics (Hoek and Bray, 1981; Guzzetti et al., 1999; Carere et al., 2001; Crosta et al., 2001). Many methods for the assessment of landslide hazard are based on data processing linked to Geographical Information Systems (GIS). Three types of approaches can be distinguished (Guzzetti et al., 1999; Crosta et al., 2001):

1. Methods comparing the distribution of observed landslides (by means of an inventory) with the distribution of physical factors thought to cause landslides either directly or indirectly. These methods use statistical techniques (Carrara, 1983; Carrara et al., 1995; Chung et al., 1995).

2. Heuristic or multi-criterion methods (Leroi, 1996) associating weights to various instability factors, based on expert experience (Wagner et al., 1990; Gupta et al., 1999; Meissina et al., 2001). 


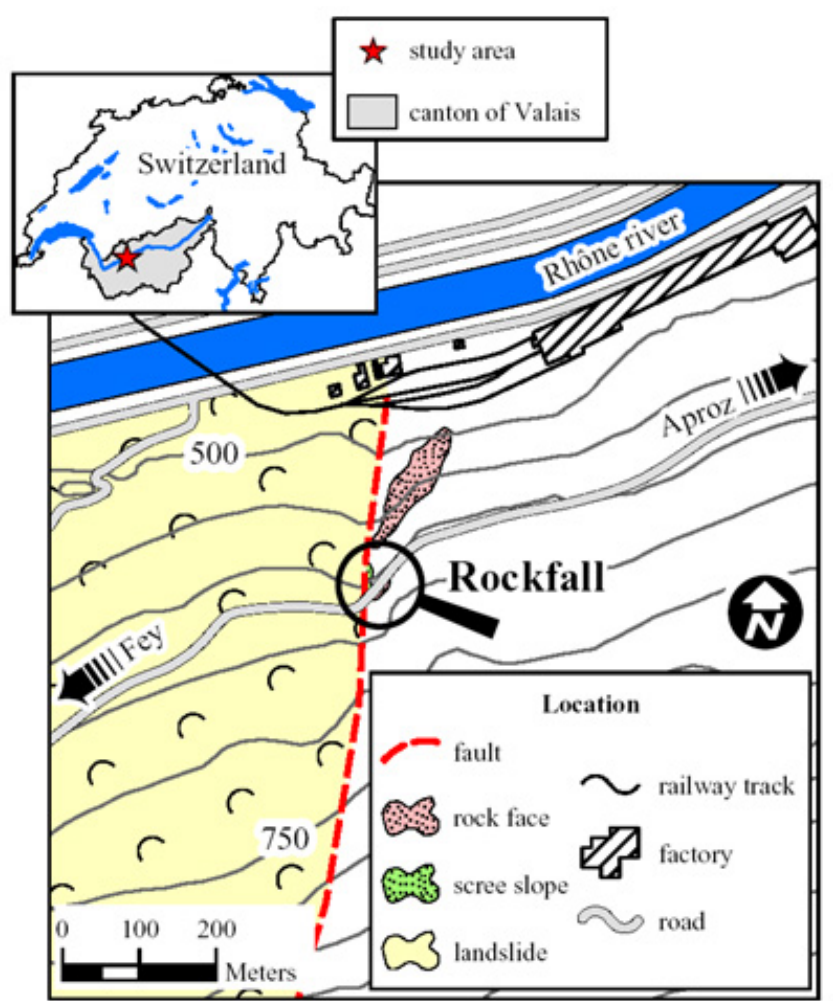

Fig. 1. Slope instability map. The rockfall occurred in an area affected by a fault and possessing a scree slope, a rock cliff, a steep slope and a road.

3. Physically-based approaches that evaluate stability using physical laws (Terlien et al., 1995).

The method employed in this study belongs to the second type. It is based on the analysis of topographic, geomorphological and geological parameters derived from the location of the observed rockfall. The parameters are chosen so that they can be easily mapped and integrated in a GIS.

\section{The Eterpas event}

The Eterpas rock cliff is located directly above the road, and displays slope ravelling resulting from periods of snow melt and heavy rainfall. The scree slope located at its toe confirms this assessment (Figs. 1 and 2).

The rock cliff consists of a succession of shaly sandstones and schists with coal layers belonging to the "Zone Houillère Inférieure" (Escher et al., 1997), topped by a moraine containing gypsum blocks. A fault several km long forms a small scarp to the west of the rockfall (Fig. 1). This fault is located less than $50 \mathrm{~m}$ from the instability. It can be seen on aerial photographs and marks the eastern limit of a landslide, affecting an area of about $0.3 \mathrm{~km}^{2}$.

Approximately $2000 \mathrm{~m}^{3}$ of rock came from a subvertical, 30-m-high cliff on 9 January 2001, at 17:30. The rockfall obstructed the road between Aproz and Fey, at a place called

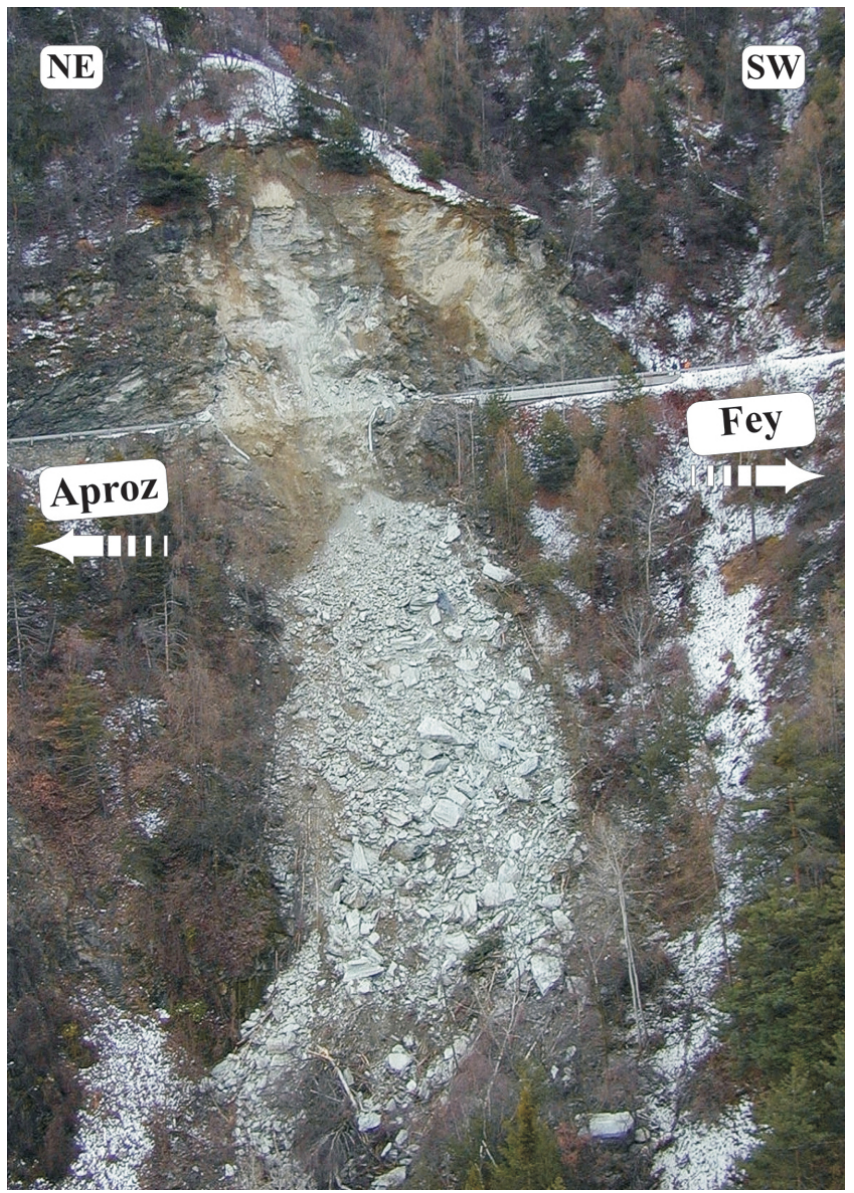

Fig. 2. The Eterpas area after the 9 January 2001, rockfall (photo J.-D. Rouiller). The 30-m-high sub-vertical rock cliff overhanging the road collapsed at 17:30, blocking the road.

"Eterpas" (Figs. 1 and 2). As reported by witnesses, precursory rockfalls $\left(<20 \mathrm{~m}^{3}\right)$ occurred as early as $16: 15$, for about an hour. At the same time, silty water flowed out from the toe of the rock cliff. This observation confirms the continuity and aperture of the joints. Shortly before the main rockfall, the rock mass began to bulge out at its base. A cloud of dust accompanied the rockfall.

\subsection{Structural survey}

The a posteriori structural survey highlights six major sets of discontinuity (Fig. 3). The main schistosity (S) dips on average $30^{\circ}$ to the east-northeast. It is mostly sub-parallel to the bedding. The softest beds weaken the toe of the rock mass. The schistosity forms tension cracks. The J4 discontinuity set $(\approx 290 / 65)$ and $\mathrm{J} 5$ discontinuity set $(\approx 350 / 75)$ are slightly persistent, rough and undulating. They form wedges, whose axes dip down to the slope (295/65). The subvertical and globally north-northwest - south-southeast oriented $\mathrm{J} 1$ discontinuity set and $\mathbf{J} 2$ discontinuity set are lateral shear planes. Dipping to the south, the J3 discontinuity set forms tension cracks. 


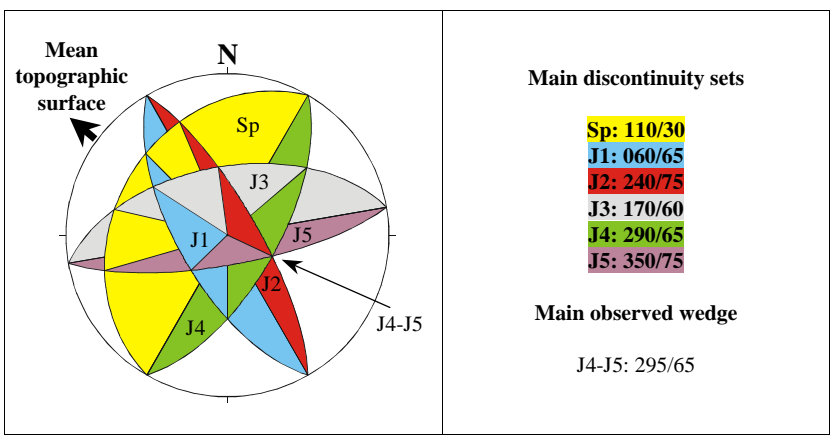

Fig. 3. Stereonet displaying the main discontinuity sets (SchmidtLambert, upper hemisphere). The upper hemisphere is used in order to display the wedges.

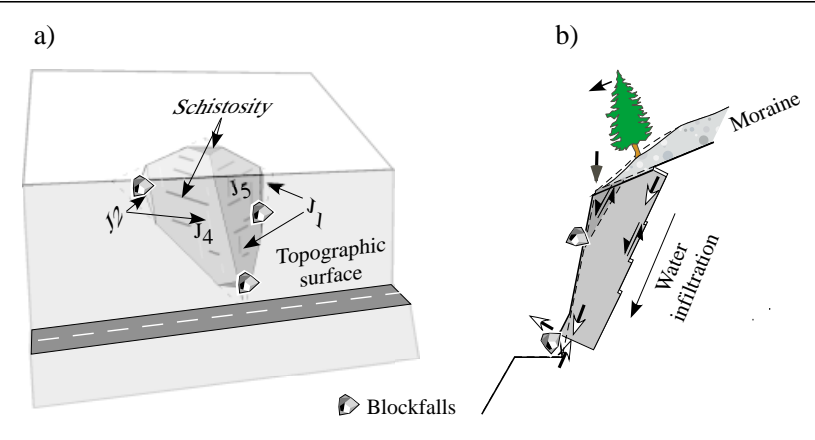

Fig. 4. Sketch of the failure mechanism. (a) unstable rock wedge; (b) the bulging of the rock mass that occurred before the final failure indicates that maximum compression was located at the toe of the rock wedge.

A J4-J5 wedge built by composite stepped surfaces J4-S and S-J5 defines the unstable rock mass. $\mathrm{S}$ forms the rear tension cracks. Small rockfalls $\left(<20 \mathrm{~m}^{3}\right)$ that occurred before the main event essentially took place (1) along the lateral boundaries formed by the discontinuous $\mathrm{J} 1$ and $\mathrm{J} 2$ shear planes, (2) at the toe of the unstable wedge, and (3) at the top of the rock cliff (Fig. 4). This progressive dismantling indicates a loss of resistance along the discontinuities and/or a failure of the buttress. The latter indicates that the area of maximum compression was actually located at the toe of the wedge (Fig. 4), lying on a weaker bed parallel to the foliation. Despite this unfavourable geometry - a result of the construction of the road in the 1950's - the rock wedge subsequently remained stable.

\subsection{Cause of the failure}

The presence of the road is the major long-term factor affecting the stability of the rock mass. At the time of the construction of the road, the buttress of the compartment was reduced and consequently, stresses increased in its base. Groundwater probably weathered the surfaces of the rock and joints,
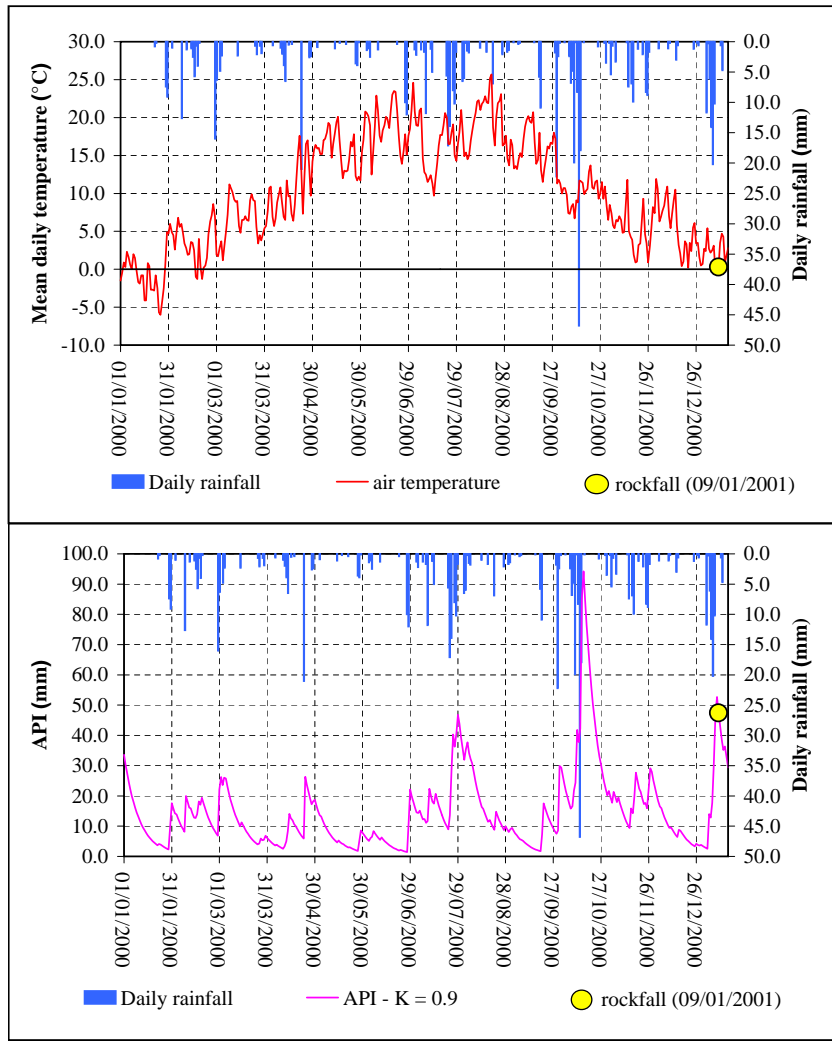

Fig. 5. Meteorological conditions occurring during the days before the rockfall. Daily rainfall (from 07:00 to 07:00), calculated Antecedent Precipitation Index $(A P I)$ and mean daily temperature measured from 00:00 to 00:00 (data: MeteoSwiss, www.metoswiss.ch).

and modified their geomechanical characteristics. Weathering in schists is thought to be "moderately easy" (Ollier, 1969; Selby, 1993). The seismic hazard of the canton of Valais (Franzetti and Tissières, 2000) may also have induced fatigue of the rock mass (Keefer, 1994).

The hypothesis of a triggering earthquake can be excluded. Only a minor earthquake (Richter's magnitude of 1.7) was recorded on 9 January 2001, at 04:25 and $230 \mathrm{~km}$ from the study area (data: Swiss Seismological Service: Earthquake Catalogues of Switzerland: http://www.seismo.ethz.ch/).

Antecedent meteorological conditions probably influenced the rockfall event. The nearest weather station is located approximately $2.2 \mathrm{~km}$ from the study area, at Fey. No rainfall was recorded on 9 January 2001 (Fig. 5). A simple and relevant hydrological index to assess the influence of precipitation on rockfall is the Antecedent Precipitation Index $(A P I)$. The $A P I$ is based on the amount of rainfall that occurs before a given day. It assumes a logarithmic decrease of the soil moisture content with time during a period of no rainfall. The $A P I_{d}$ gives an indication of the moisture conditions before an event using the precipitations of the $d$ preceding days. The $A P I_{d}$ is estimated using the following 
expression (Jaton et al., 1978; Musy and Higy, 1999):

$A P I_{d}=A P I_{d-1} \cdot K+P_{d-1}$

or:

$A P I_{d}=\sum_{n=1}^{n=d-1} K^{n-1} P_{d-n}$

where:

$A P I_{d}$ antecedent precipitation index on day $d(\mathrm{~mm})$

$P_{d-n}$ rainfall on day $d-n(\mathrm{~mm})$

$K \quad$ coefficient varying between 0.8 and 0.9 , assumed

to be 0.9 for this study by analogy with other studies performed in Switzerland (Jaton et al., 1978)

The API was calculated for the period 1 January 2000 to 15 January 2001 (Fig. 5). Two peaks appear during this period: the first one corresponds to an October 2000 storm (FOWG, 2002), and the second peak begins two days before the rockfall. No rockfall occurred during October 2000 at the Eterpas. However, displacements and rockfalls were reported in many of the sites monitored in the canton of Valais (FOWG, 2002). The high API supports the assumption that the Eterpas rock mass was saturated in January 2001. Diurnal freeze and thaw cycles may have played a role in triggering the event (Brawner, 1994). On 9 January temperatures ranged between -1.8 and $1.8^{\circ} \mathrm{C}$. The mean value was $0.3^{\circ} \mathrm{C}$ (Fig. 5). Damage linked to freeze and thaw cycles increases if antecedent moisture conditions are high (Matsuoka et al., 1998; Wegmann, 1998).

\section{Relative hazard mapping}

\subsection{Principle}

As demonstrated, the Eterpas rockfall is the result of destabilizing factors acting simultaneously that resulted in a decrease of the resistance along the discontinuities and a progressive failure of the remaining rock bridges. These destabilizing factors depend on various conditions. The unfavourable topographic, geomorphological and geological settings allow the classification of the Eterpas area as a region that is susceptible to rockfall, and suggest that a regional, multi-criterion approach could be used to detect and qualify the relative hazard of rock slope instabilities in alpine contexts. The occurrence of the 2001 rockfall was not only caused by unfavourable structural settings, but also by degrading and triggering factors that were not taken into account in the present approach.

\subsection{Modeled instability factors}

Five factors of instability based on the a posteriori analysis of the Eterpas rockfall have been chosen and modeled by means of a GIS: (1) the proximity to a fault or (2) a scree slope, (3) the presence of a rock cliff, (4) a steep slope or (5) a road.
Table 1. Weights affected by "proximity of a fault" in relation to factors of instability, with various multi-criterion approaches

\begin{tabular}{lcc}
\hline Author & Distance to the fault (m) & Weight \\
\hline \multirow{3}{*}{ Wagner et al. (1990) } & $<100$ & 25 \\
& $100-300$ & 13 \\
& $>300$ & 0 \\
\hline \multirow{3}{*}{ Gupta et al. (1999) } & $<500$ & 9 \\
& $500-1000$ & 6 \\
& $>1000$ & 3 \\
\hline & $<20$ & 2.0 \\
Meisina et al. (2001) & $20-50$ & 1.7 \\
& $50-100$ & 1.4 \\
& $100-200$ & 1.2 \\
& $>200$ & 1.0
\end{tabular}

These factors relate to topographic, geomorphological and geological settings. The ArcView software (ESRI) was used in this analysis.

The study was carried out using a $25 \mathrm{~m}$ grid size DTM and manual digitization of the road, the cliff, the scree slope and the fault from 1:10000 topographic and geological maps. The vector dataset (vector25) derived from the 1:25000 Swiss topographic maps were not available at the time of this analysis.

Fault. Large-scale structures like faults or thrusts induce regional perturbations in the fracturing density, and also in the circulation of water (Wagner et al., 1990; Ferrill and Morris, 2001; Kellogg, 2001). Using a survey of 205 slope instabilities along a mountainous road in Nepal, Wagner et al. (1990) showed that the lateral influence of faults on instability density could reach $300 \mathrm{~m}$. The Eterpas instability is located near a fault, as shown on available maps (Steck et al., 2001; Sartori, in prep.). The area of influence of a fault has to account for location errors (scale effects, mapping uncertainty), as well as the effect of the fault itself. A $150 \mathrm{~m}$ buffer was then assigned on each side, in accordance with comparable expert approach systems (Table 1).

Scree slope. The presence of a scree slope below the rock cliff suggests slope ravelling activity. This activity can be linked to the progressive failure of the rock cliff, but can also be a precursory event of larger rockfalls (Sartori et al., 2003). A $100 \mathrm{~m}$ buffer was chosen on the outside of the limits of the scree slope, in order to include the source area. The minimum size of the considered scree slopes depends on the scale of the base document used for the digitization. All scree slopes appearing in the base document are considered in this study.

Rock cliff. The presence of a rock slope instability is usually linked to the presence of a rock cliff. Cliffs are rock outcrops from the geological or the topographic maps. As a consequence, their minimum size depends on the scale of the base document used for digitization. All cliffs appearing in the base document are considered in this study. 


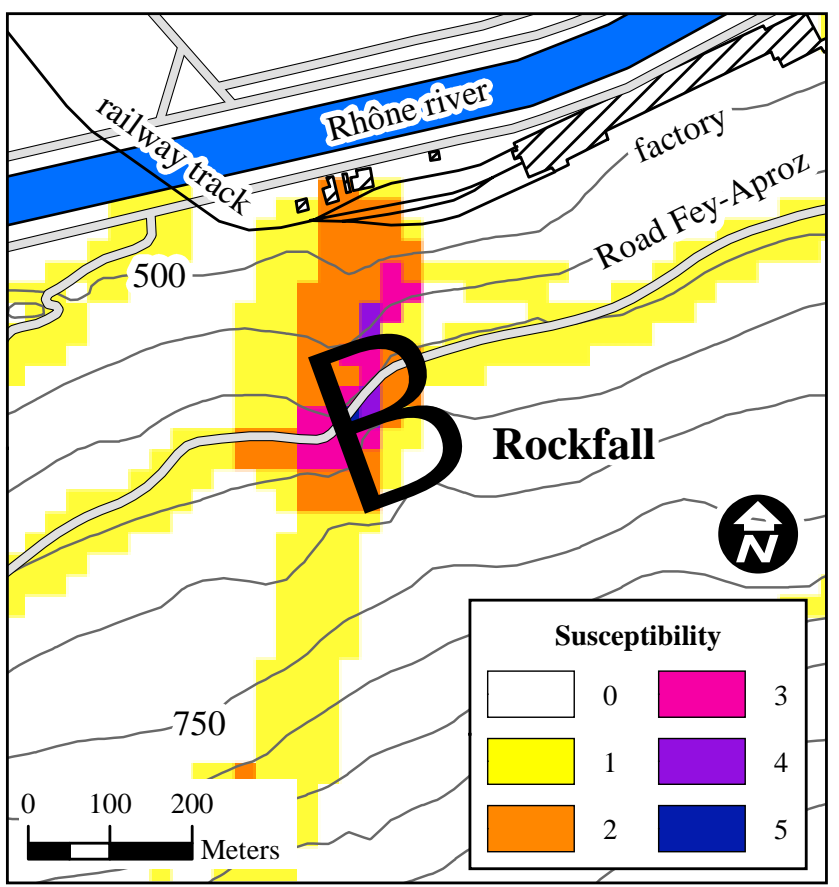

Fig. 6. Automatic assessment of susceptibility using five criteria at the Eterpas area. The criteria used: (1) the proximity to a fault or (2) a scree slope, (3) the presence of a rock cliff, (4) a steep slope, or (5) a road. This area has a maximum susceptibility index value reaching 5. According to this approach, the susceptibility to producing a rockfall is high.

Steep slope. Rock slope instabilities occur in steep slopes (Rouiller et al., 1998). The adopted cut off value for slope gradient above which a rock slope instability may occur is $45^{\circ}$, by analogy with other approaches that give higher values to steeper slopes (Gupta et al., 1999; Meissina et al., 2001). The slope map was calculated using the $25 \mathrm{~m}$ grid size DTM (level 1; www.swisstopo.ch). The standard ArcView processing was used (Horn, 1981), which is considered as better for rough surfaces (Burrough and McDonnel, 1998).

Road. A distance of $50 \mathrm{~m}$ above the road was chosen (maximum height of a talus cut created by the construction of a road). This parameter has been taken into account by other researchers (Chung et al., 1995).

Each parameter was then transformed to a raster format. The sum of the 5 parameters leads to a relative hazard map for which the scale ranges from 0 to 5 (Figs. 6 and 7).

\subsection{Results}

The method must now be applied at a larger scale using the newly available documents, such as tectonic maps (Steck et al., 2001), vector 25 or digitized thematic maps at a 1:10000 scale, all of which were not available as this article was being written.

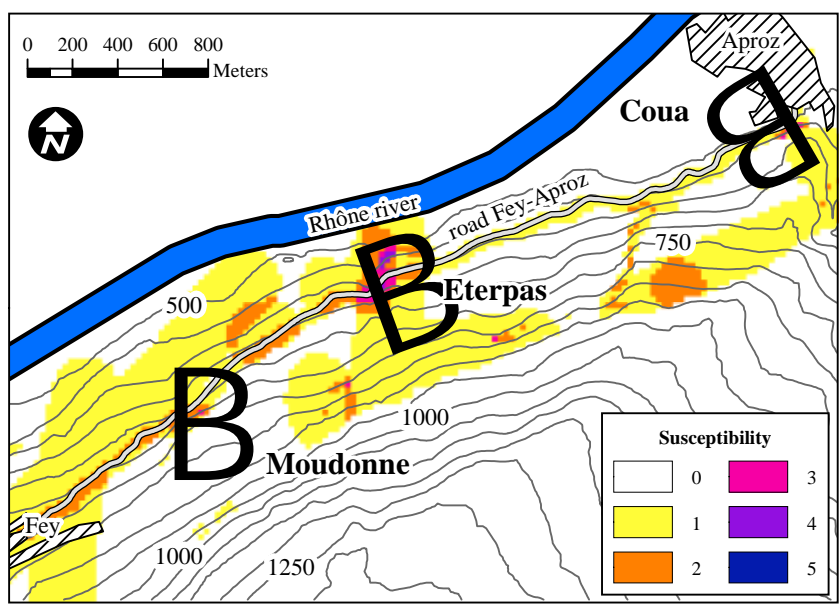

Fig. 7. Automatic detection of susceptible areas along the road joining Aproz and Fey. Besides the Eterpas area, two more areas along this road have high susceptibilities to producing rockfalls.

The area of the Eterpas rockfall has a maximum relative hazard value of 5 , which means that its susceptibility to experiencing a rockfall is high (Fig. 6). Its susceptibility to failure is also high if one considers two additional criteria:

- The local structural pattern has to be susceptible to failure (in this study, the presence of a wedge whose axis daylights in the talus cut created by the road).

- The local morphology has to be susceptible to the action of degrading and triggering factors (in this study, the presence of a gentle slope topping the rock mass and allowing the accumulation and infiltration of part of the runoff water, and exposure of the rock mass to the north favouring freeze and thaw processes).

This method of detection and hazard assessment was applied to the entire length of the road joining Aproz and Fey (Fig. 7). The Eterpas area is the only one with a relative hazard of 5. Additionally, two other locations have high relative hazard values, and are thus areas from which rockfalls might originate:

- The Coua rock cliff is characterized by a maximum susceptibility of 3. A field survey shows that this area is indeed the site of a $2000 \mathrm{~m}^{3}$ rock instability. The geological study performed in 1998 describes a potential J5-S wedge sliding (BEG S.A., 1998).

- The Moudonne rock cliff has a maximum susceptibility of 4 . A $1000 \mathrm{~m}^{3}$ unstable rock mass can be delimited. Its potential failure mechanism is similar to the Eterpas instability. Rockfalls can be seen at the bottom of the rock mass. Unfortunately, it is impossible to determine their freshness, because the unstable mass is covered with a geotextile net that prevents small rockfalls from hitting the road. 


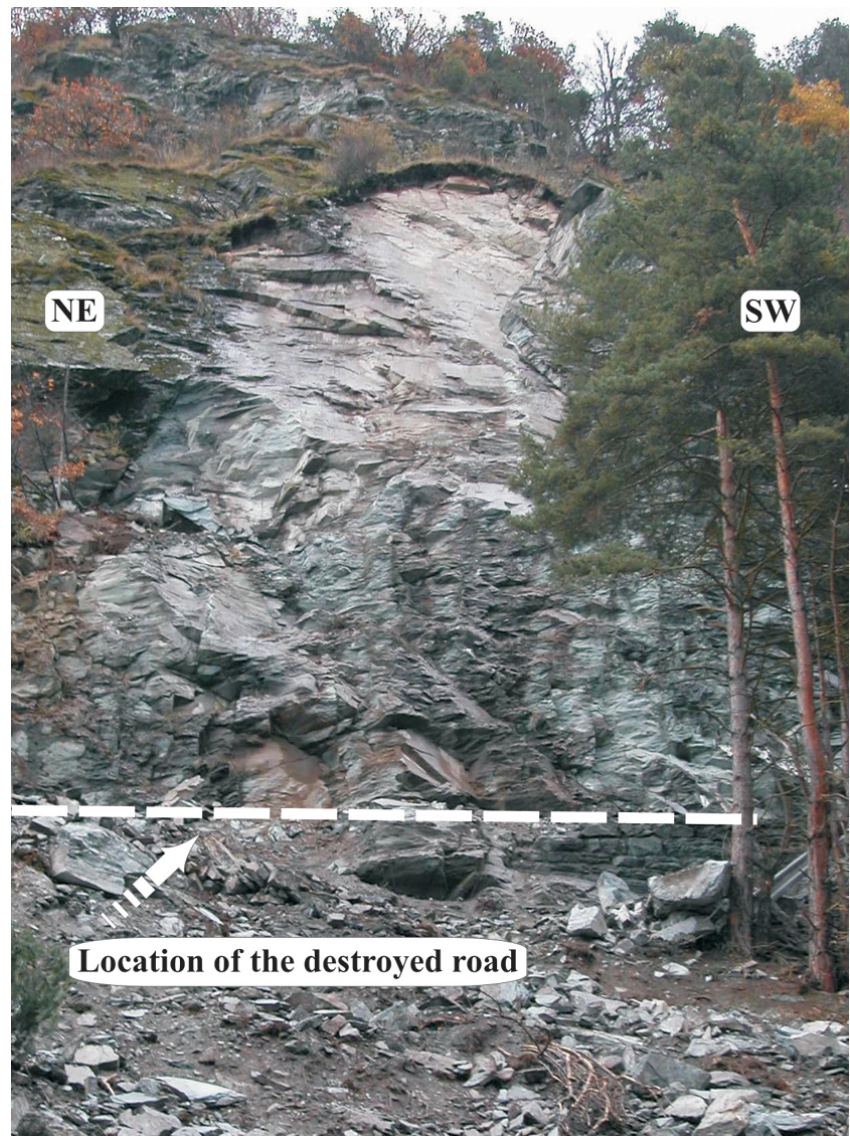

Fig. 8. Photo of the 04 November 2002 Chalais rockfall (photo J.-D. Rouiller).

\section{Discussion and conclusions}

The sum of the five relevant parameters allowed the rapid production of a relative hazard map. The analysis of instability factors related to topographic, geomorphological and geological settings shows that the Eterpas area was highly sensitive to rock instability. The application of this method to the entire length of the road reveals two other unstable areas. One of those has been monitored since 1998. A field survey showed that a slope of instability was present at the other location.

In a previous large-scale study dedicated to the Crétaux rockfall (4.4 km southeast from the Eterpas) that occurred in 26 August 1985 (Descoeudres, 1990), a "high to very high hazard" was attributed to the Eterpas rock cliff (Wagner et al., 1990). Due to its location at the border of the study area, this rock cliff was not extensively studied. The method used by Wagner et al. (1990) produces susceptibility maps semi-automatically with a software named "SHIVA" and is based on parameters related to lithology (like hardness or alteration), fracturing, topography and hydrogeology. The present approach is less time-consuming than the one used by Wagner et al. (1990). The parameters outlined in this study are easy to obtain, and may, for example, be derived from the

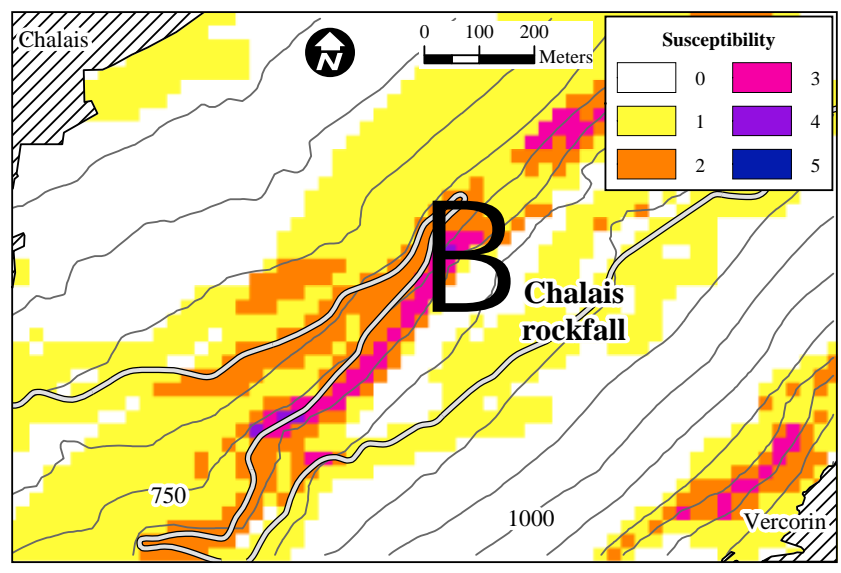

Fig. 9. Automatic susceptibility assessment at the 04 November 2002 Chalais rockfall.

Swiss 1:25000 topographic digitized map. Thus the present method yields rapid results. Very few additional field surveys or data processing is necessary.

Questions arise concerning the relevance of the five chosen parameters: are they exclusive or are some of them redundant? Only the "slope" and the "rock cliff" parameters may be redundant. In any event, the presence of a steep slope is the most important parameter characterizing susceptibility to rock instabilities. As steep slopes can affect areas without rock outcrops, the presence of a rock cliff was chosen as an additional controlling factor. Furthermore, the grid size of the DTM used $(25 \times 25 \mathrm{~m})$ doesn't allow for the detection of small rock cliffs by means of the "slope" parameter. Thus the use of both "slope" and "rock cliff" parameters allows higher susceptibility values to be assigned to steep and high slopes. All remaining parameters are unique and mutually exclusive.

The proposed multi-criterion approach allows priority to be assigned to areas displaying a high sensitivity to rockfall instability when considering instability factors related to topographic, geomorphological and geological settings. These results must of course be combined with other instability factors in order to determine the susceptibility to failure of single unstable rock masses. Highly rated areas are more likely to contain rock slope instabilities than lower ones, but the hazard is increased only if local structural settings and sensitivity to degrading and triggering factors are conducive to failure. Identification of phenomena leading to potential instability for given structural conditions is realized by field surveys, but part of this treatment can be performed automatically (Rouiller et al., 1998).

The next step will be to enhance the present approach by including instability factors that relate to structure and sensitivity to degrading and triggering conditions, as well as to limit the buffer zone around scree slopes to the upslope side only. A database of catastrophic events will then be used to quantify the temporal probabilities of occurrence (Hantz et al., 2001; Dussauge-Peisser et al., 2002). The identification 
of areas with identical probabilities of failure could then be used in order to draw hazard maps in a semi-automatic way using available software (Utelli, 1999; Guzzetti and Crosta, 2001). The method that we propose is currently being tested on the entire canton of Valais. A rockfall occurred $20 \mathrm{~km}$ east of the Eterpas area on 4 November 2002. Six hundred cubic meters of rock fell down and destroyed the road joining Chalais and the ski resort of Vercorin (Fig. 8). Our method gives this area a high susceptibility rating (Fig. 9): "slope", "road", "steep slope" and "cliff" parameters are present.

Acknowledgements. We thank R. Bovier for his help. The comments of O. Hungr (University of British Columbia) and an anonymous reviewer helped greatly to improve the manuscript. This research is supported by the Swiss National Science Foundation (Grant Number 2100-50781.97).

\section{References}

Beg, S. A.: Route cantonale Aproz-Fey $N^{\circ}$ 67. Aléa rocheux à la sortie d'Aproz, étude structurale et géomécanique. Etude No. GC/98.126, unpublished report, 1998.

Brawner, C. O.: Rockfall Hazard Mitigation Methods, Participant Workbook, NHI Course No. 13219. U.S. Department of Transportation, Federal Highway Administration, Publication No. FHWA SA-93-085, 1994.

Burrough, P. A. and McDonnell, R. A.: Principles of Geographic Information Systems, Oxford University Press, Oxford, 333, 1998.

Carere, K., Ratto, S., and Zanolini, F. (Eds): Programme Interreg 2c - "Falaises". Prévention des mouvements de versants et des instabilités de falaises, Confrontation des méthodes d'études des éboulements rocheux dans l'arc alpin, 239, 2001.

Carrara, A.: A multivariate model for landslide hazard evaluation, Mathematical Geology 15, 403-426, 1983.

Carrara, A., Cardinali, M., Guzetti, F., and Reichenbach, P.: GIS technology in mapping landslides hazard, in: Geographical information system in assessing natural hazards, edited by Carrara, A. and Guzzetti, F., Kluwer Academic Publishers, Dordrecht, The Netherlands, 135-176, 1995.

Chung, C. F., Fabbri, A. G., and Van Westen, C. J.: Multivariate regression analysis for landslides hazard zonation, in: Geographical information system in assessing natural hazards, edited by Carrara, A. and Guzzetti, F., Kluwer Academic Publishers, Dordrecht, The Netherlands, 107-133, 1995.

Crosta, G., Frattini, P., and Sterlacchini, S.: Valutazione e gestione del rischio da frana, Regione Lombardia, Milano, 2001.

Descoeudres, F.: L'éboulement des Crêtaux, Aspects géotechniques et calcul dynamique des chutes de blocs. Publ. Soc., Suisse de Mécanique des Sols et des Roches, 121, 19-25, 1990.

Dussauge-Peisser, C., Helmstetter, A., Grasso, J.-R., Hantz, D., Desvarreux, P., Jeannin, M., and Giraud, A.: Probabilistic approach to rock fall hazard assessment: potential of historical data analysis, Natural Hazards and Earth System Sciences, 2, 15-26, 2002.

Escher, A., Hunziker, J. C., Marthaler, M., Masson, H., Sartori, M., and Steck A.: Geological framework and structural evolution of the Western Swiss-Italian Alps, in: Results of NRP 20, Deep structure of the Swiss Alps, edited by Pfiffner, O.A., Lehner, P., Heitzmann, P., Mueller, St., and Steck, A., 205-222, 1997.

Fard, M. Y.: Slope stability - Study of a real landslide in Tabriz, in: Proceedings of the 54th Canadian Geotechnical Conference, 2nd
Joint IAH and CGS Groundwater Conference, 16-19 September 2001, Calgary, Alberta, Canada, 1, 379-383, 2001.

Ferrill, D. A. and Morris, A. P.: Displacement gradient and deformation in normal fault systems, Journal of Structural Geology, 23, 619-638, 2001.

FOWG, Federal Office for Water and Geology: Hochwasser $2002-$ Les crues 2002, Rapports de l'OFEG, Série Eaux, 2, Bern, 248, 2002.

Franzetti, F. and Tissières, P.: Guide de construction parasismique, Crealp, rapport 99.06, Sion, 2000.

Gupta, R. P., Saha, A. K., Arora, M. K., and Kumar A.: Landslide Hazard Zonation in part of the Bhagirathi Valley, Garhwal Mimalyas, using integrated remote sensing - GIS, Himalayan Geology, 20, 71-85, 1999.

Guzzetti, F. and Crosta, G.: Programma Stone: Un programma per la simulazione tridimensionale delle cadute massi, in: Programme Interreg IIc - "Falaises", Prévention des mouvements de versants et des instabilités de falaises, edited by Carere, K. Ratto, S., and Zanolini, F., Confrontation des méthodes d'études des éboulements rocheux dans l'arc alpin, 70-79, 2001.

Guzzetti, F., Carrara, A., Cardinali, M., and Reichenbach, P.: Landslides hazard evaluation: a review of current techniques and their application in a multi-scale study, Central Italy, Geomorphology, 31, 181-216, 1999.

Hantz, D., Vengeon, J.-M., and Dussauge, C.: Approche historique, géomécanique et probabiliste de l'aléa éboulement rocheux, 15ème congrès français de mécanique, Nancy, 1-6, 2001.

Hoek, E. and Bray, J.: Rock slope engineering. Revised third edition. E \& FN Spon, London, 358, 1981.

Horn, B. K. P.: Hill shading and the reflectance map, Proceedings of the IEEE 69/1, 1-47, 1981.

Jaton, J. F., Musy, A., and Regamey, P.: Méthode de prédétermination des débits de ruissellement basée sur l'état de saturation antérieure du bassin, Communication à l'OCDE, Berne 1978. Publication IGR No. 142, EPF-Lausanne, 1978.

Keefer, D. K.: The importance of earthquake-induced landslides to long-term slope erosion and slope-failure hazards in seismically active regions, Geomorphology, 10, 265-284, 1994.

Kellogg, K. S.: Tectonic controls on a large landslide complex: Williams Fork Mountains near Dillon, Colorado, Geomorphology, 41, 355-368, 2001.

Leroi, E.: Landslides hazard - risk maps at different scales: objectives, tools and developments, Proceedings of the 7th Int. Symp. on Landslides, Trondheim, Norway, 1, 35-51, 1996.

Matsuoka, N., Hirakawa, K., Watanabe, T., Haeberli, W., and Keller, F.: The role of diurnal, annual and millennial freeze-thaw cycles in controlling alpine slope instability, in: 7th International Permafrost Conference, edited by Lewkowicz, A. G. and Allard M., Yellowknife, Canada, 711-717, 1998.

Meisina, C., Piccio, A., and Tocchio, A.: Some aspects of the landslide susceptibility in the Sorba Valley (western Alps, Italy), in: International Conference on Landslides - Causes, Impacts and Countermeasures, edited by Kühne, M., Einstein, H. H., Krauter, E., Klapperich, H., and Pöttler, R., 17-21 June 2001, Davos, Switzerland, VGE, Essen, 547-556, 2001.

Musy, A. and Higy, C.: Hydrologie appliquée, cours polycopié, sections: génie rural, environnement, mensuration et génie civil, 1999.

Ollier, C. D.: Weathering, American Elsevier, New-York, 304, 1969.

Rouiller, J.-D., Jaboyedoff, M., Marro, C., Philippossian, F., and Mamin, M.: Pentes instables dans le Pennique valaisan, Mat- 
terock: une méthodologie d'auscultation des falaises et de détection des éboulements majeurs potentiels. Rapport final PNR31, VDF, Zürich, 239, 1998.

Sartori, M.: Atlas géologique Suisse 1:25000, feuille No. 1306 Sion, Service hydrologique et géologique national, Bern, in prep.

Sartori, M., Baillifard, F., Jaboyedoff, M., and Rouiller, J.-D: Kinematics of the 1991 Randa rockslides (Valais, Switzerland), Natural Hazards and Earth System Sciences, this issue, 2003.

Selby, M. J.: Hillslope materials and processes, second edition, Oxford University Press, Oxford, 451, 1993.

Steck, A., Epard, J.-L., Escher, A., Gouffon, Y., and Masson, H.: Carte tectonique des Alpes de Suisse occidentale et des régions avoisinantes 1:100000. Carte géologique spéciale No. 123. Office fédéral des eaux et de la géologie, Bern, 2001.

Terlien, M. T. J., Van Asch, T. W. J., and Van Westen, C. J.: Deterministic modeling in GIS-based landslide hazard assessment, in: Geographical information system in assessing natural haz- ards, edited by Carrara, A. and Guzzetti, F., Kluwer Academic Publishers, Dordrecht, The Netherlands, 57-77, 1995.

Turner, A. K. and Schuster, R. L. (Eds): Landslides, Investigation and Mitigation, Transportation Research Board, Special Report 247, National Research Council, National Academy Press, Washington D.C., 673, 1996.

Utelli, H.-H.: Die Möglichkeiten von GIS bei der Beurteilung der Steinschlaggefahr im alpinen Bereich, Bull. Angew. Geol., 4/1, 3-17, 1999.

Wagner, A., Leite, E., and Olivier, R.: SHIVA, a landslide hazard mapping software, Vol. 1: Users guide, Vol. 2: Annexes and case studies, Inst. Géoph. Université de Lausanne and ITECO, Affoltern a.A., 1990.

Wegmann, M.: Frostdynamik in hochalpine Felswänden am Beispiel des Region Jungfraujoch - Aletsch, Mitteilungen, 161. Versuchsanstalt für Wasserbau, Hydrologie und Glaziologie des Eidgenössischen Technischen Hochschule Zürich, 144, 1998. 